\title{
Genetic divergence among Brazilian garlic cultivars based on morphological characters and AFLP markers
}

R.G.F. Morales ${ }^{1}$, J.T.V. Resende ${ }^{1}$, F.V. Resende ${ }^{2}$, C.A. Delatorre ${ }^{3}$, A.S.T. Figueiredo ${ }^{1}$ and P.R. Da-Silva ${ }^{4}$

${ }^{1}$ Departamento de Agronomia, Universidade Estadual do Centro-Oeste, Guarapuava, PR, Brasil

${ }^{2}$ Empresa Brasileira de Pesquisa Agropecuária, Centro Nacional de Pesquisa de Hortaliças, Brasília, DF, Brasil

${ }^{3}$ Universidade Federal do Rio Grande do Sul, Porto Alegre, RS, Brasil

${ }^{4}$ Laboratório de Genética e Biologia Molecular Vegetal,

Departamento de Ciências Biológicas, Universidade Estadual do Centro-Oeste, Guarapuava, PR, Brasil

Corresponding author: P.R. Da-Silva

E-mail: prsilva@unicentro.com

Genet. Mol. Res. 12 (1): 270-281 (2013)

Received February 6, 2012

Accepted October 18, 2012

Published February 4, 2013

DOI http://dx.doi.org/10.4238/2013.February.4.1

ABSTRACT. Outside its centers of origin, garlic propagates only asexually. Since asexual reproduction leads to the absence of meiotic recombination, the main garlic cultivars available for cultivation have arisen from the accumulation of somatic mutations in early cultivars. Thus, it is common for a single clone to have different names in different regions. This study aimed to evaluate the genetic diversity of 20 garlic cultivars by using morphological characters and amplified fragment length polymorphism (AFLP) markers to identify possible duplicate cultivars. We assessed 28 morphological characters related to the leaves, bulbs, and bulbils of the garlic plant and divided them into two categories: quantitative and qualitative (14 characters each). 
For molecular marker-based analysis, we used three AFLP primer combinations. Genetic divergence was calculated using the Jaccard coefficient; the cultivars were grouped using unweighted pair-group mean analysis. The average genetic divergence detected using the morphological characters was 2.30 (range, $0.45-4.70$ ). Plant height and coat adhesion exhibited the highest divergence among the cultivars. The average genetic diversity based on AFLP data was $43 \%$ (range, $0-79 \%$ ). Dendrograms derived from both techniques divided the cultivars into two groups: noble and semi-noble. Together with the divergence within groups, the correlation between morphological and molecular data suggested that the cultivars in the noble group had greater phenotypic stability than those in the semi-noble group. Analysis of Jonas and Quitéria cultivars using these two techniques revealed only slight differences, suggesting that these cultivars may be clones or have a high degree of kinship.

Key words: Allium sativum L.; Clones; Genetic divergence; Molecular markers

\section{INTRODUCTION}

Garlic (Allium sativum $\mathrm{L}$.) is a diploid species $(2 \mathrm{n}=2 \mathrm{x}=16)$ belonging to the Alliaceae family that originated in the temperate regions of Central Asia (Etoh et al., 2001). It is one of the most cultivated vegetables in the world. Garlic ranks fourth in economic importance out of all the vegetables grown in Brazil, surpassed only by potato, tomato, and onion (Filgueira, 2008).

Outside its centers of origin, garlic reproduction occurs by vegetative propagation. This type of reproduction does not allow meiotic recombination, making it impossible to obtain genetic recombinants and hindering the development of cultivars that are adapted to different growing conditions (Vieira and Nodari, 2007). Thus, the available cultivars of garlic are a result of the accumulation of somatic mutations in the basic crop material. The origin of most of these cultivars is uncertain. This is true of the large number of cultivars found in the Brazilian markets; however, many of these are the same but have different names in different regions (Mota et al., 2006).

Currently, several methods enable the genetic characterization of cultivars. These methods differ in their ease of use, cost, and reproducibility of results (Li et al., 2010). Methods previously used to study the genetic diversity in garlic can be divided into three groups, i.e., methods based on morphological markers (Pooler and Simon, 1993; Baghalian et al., 2006), those based on biochemical markers (Pooler and Simon, 1993; Lallemand et al., 1997), and those based on DNA markers (Bark and Havey, 1995; Maab and Klaas, 1995; Lampasona et al., 2003; Volk et al., 2004; Ovesná et al., 2007; Buso et al., 2008).

At present, morphological markers are primarily used to distinguish between garlic cultivars (Menezes Sobrinho et al., 1999). However, morphological markers have limitations, mainly because they are directly affected by the environment, which often makes their evaluation unreliable. In addition to environmental factors, most of these markers can only be evaluated in adult plants, which not only require time and space for plant growth but also increase 
the cost of analysis (Vieira and Nodari, 2007). Another problem with this analysis is that there are few morphological markers described in the literature, which is a limiting factor for the differentiation of cultivars under study.

In view of the limitations of morphological markers, there is a need to use better techniques in parallel for more precise detection of the differences between cultivars under study (Morales et al., 2011). Among the available DNA-based molecular markers, amplified restriction fragment length polymorphism (AFLP) markers have been successfully used to study the genetic divergence and identification of garlic clones (Volk et al., 2004; Ovesná et al., 2007). These markers are not affected by environmental factors and provide extensive genome coverage (Vos et al., 1995).

The combined use of morphological characters and AFLP markers allows greater genome coverage by granting access to different regions of DNA simultaneously, thus allowing accurate inferences of the genetic divergence between cultivars. The objective of this study was to evaluate the genetic diversity of 20 garlic cultivars by combining morphological characters and AFLP molecular marker data.

\section{MATERIAL AND METHODS}

\section{Site of evaluation and description of plant material}

The experiments were conducted between May and October 2009 at Guarapuava, south of Paraná State, Brazil. According to the Koppen classification, the climate of the site is subtropical humid mesothermal $(\mathrm{Cfb})$ with no dry season, and has cool summers and mild winters. The annual average minimum temperature is $12.7^{\circ} \mathrm{C}$, the annual average maximum temperature is $23.5^{\circ} \mathrm{C}$, the relative humidity is $77.9 \%$, the average annual rainfall is $1944 \mathrm{~mm}$, and the elevation is approximately $1100 \mathrm{~m}$ (Thomaz and Vestena, 2003).

Twenty garlic cultivars (supplied by EMBRAPA) were used in this study. Eight were from the noble group (Caçador, San Valentin, Bergamota, Ito, Jonas, Roxo Caxiense, Quitéria, and Chonan), which are characterized by a spherical head, uniform bulbs with a white robe and pink film, large bulbils, dark pink film, and no sticks (Mota et al., 2006). The remaining 12 cultivars were from the semi-noble group (Chinês Real, Amarante, Hozan, Caturra, Gravatá, Gigante do Núcleo, Chinês São Joaquim, Cateto Roxo, Gigante Livinia, Peruano, Gigante Roxo, and Gigante Roxão), which are characterized by irregular heads, uneven bulbs, white tunic with a slightly purplish white film, and the presence of sticks (Mota et al., 2006).

\section{Experimental design and cultivation methods}

The 20 varieties of garlic were planted in $1.5-\mathrm{m}$ long and $1-\mathrm{m}$ wide plots. Plots were arranged in a randomized block design with three replications. Plants within rows were spaced $0.1 \mathrm{~m}$ apart, and the rows were separated by $0.2 \mathrm{~m}$. A total of 75 plants of each cultivar were planted per experimental unit.

Soil fertilization was divided into two stages: fertilization on planting and topdressing fertilization. Fertilization on planting was based on soil analysis and involved the application of $200 \mathrm{~g}$ NPK (nitrogen, phosphorus and potassium) (4:14:8) per plot. Topdressing fertilization was performed on 20,40 , and 60 days after planting by using $12 \mathrm{~g}$ urea and $16 \mathrm{~g}$ potassium chloride 
per plot. Pest control was performed using three sprays of mancozeb $(2.0 \mathrm{~kg} / \mathrm{ha})$ to prevent the development of rust (Puccinia allii) and alternaria (Alternaria porri). To control mites and thrips, thiometon was applied every 30 days. The crop was kept free of weeds by hand weeding.

\section{Analysis of morphological characters}

Twenty-eight morphological characters were assessed, 14 qualitative and 14 quantitative. Vegetative characters were evaluated 100 days after planting, and non-vegetative characters were evaluated after the bulbs were harvested. Ten plants and 10 bulbs of each replication were used for this analysis. The qualitative characters were evaluated according to the grading scale proposed by the Brazilian National Plant Variety Protection Systems (SNPC, 2012). Foliage density, intensity of green color, and shape of the cross section were evaluated from the leaves. The position and distribution of bulbils, presence of external bulbils (unseated), position of the root disk, base format, background color of the robe, and anthocyanin streaks of the tunic were evaluated from the bulbs. Coat color, color intensity of the tunic, tunica anthocyanin streak, flesh color, and presence of sticks were evaluated from the bulbils. The quantitative characters evaluated were as follows: average weight of bulbs, average height of plants, length of largest leaf, width of middle portion of the largest leaf, width and height of pseudo-stem, width and size of bulbs and bulbils (calculated by multiplying the height with the width), number of bulbils, and coat adhesion (determined by the average time required for two people to completely remove the coats from six bulbs).

\section{Statistical analysis}

The morphological data were analyzed using analysis of variance (ANOVA; $\mathrm{P}<0.05$, and the quantitative characters were compared using the Scott-Knott test $(\mathrm{P}<0.05)$. The characters that were not significantly different between the cultivars $(\mathrm{P}>0.05)$ were not used for the estimation of genetic divergence.

Initially, we obtained two dissimilarity matrices by taking into account the features of the evaluations performed. Data from qualitative characters (multi-categorical) were subjected to multivariate analysis to obtain the matrix of genetic dissimilarity between the cultivars. The Mahalanobis distance $\left(\mathrm{D}^{2}\right)$, as implemented in the GENES software (Cruz, 2006), was used as a measure of dissimilarity when analyzing the quantitative data. The matrices were standardized by dividing the value of each element by the standard deviation of its matrix to reduce the amplitude of variation for each. From the new dissimilarity matrix obtained using the standard values, we obtained a joint matrix whose elements are provided by means of standardized distances obtained from each data set. The joint dissimilarity matrix was used to construct a dendrogram based on UPGMA. The fit between the distance matrix and the dendrogram was evaluated using the coefficient of cophenetic correlation (r) (Sokal and Rohlf, 1962) using the NTSYSpc 2.1 software (Rohlf, 2000). The relative contribution of each quantitative character on cultivar differentiation was calculated using the Singh method (Singh, 1981).

\section{AFLP marker analysis}

The DNA of each garlic cultivar was extracted according to the protocol proposed by 
Murray and Thompson (1980). For AFLP marker analysis, we used a modified version of the protocol described by Vos et al. (1995). Briefly, 250 ng DNA from each garlic cultivar was digested separately with two restriction enzymes: $5 \mathrm{U}$ MseI and $5 \mathrm{U} P s t \mathrm{I}$. The restriction digest fragments were linked to PstI (Pa1.1 + Pa1.2) and MseI (Ma1.1 + Ma1.2) adapters (25 mM MseI adapter and $2.5 \mathrm{mM}$ Pst I adapter) with a binding buffer containing ATP, 1 U T4 DNA ligase, and ultrapure water to a final volume of $50 \mu \mathrm{L}$. Pre-amplification was performed using primers complementary to the PstI and MseI adapters (MC00 and PA00 primers). Using the pre-amplification product as the template, selective amplification was then performed using three different primer combinations (PAGA/MCAG, PAAT/MCAA, and PATA/MCTC). The sequences of the adapters and primers used are listed in Table 1. After selective amplification, the products were resolved by electrophoresis on $6 \%$ polyacrylamide gel at a constant current of $1500 \mathrm{~V}$ for $4 \mathrm{~h}$ and visualized by silver nitrate staining.

Table 1. Codes and sequences of the adapters and primers used for AFLP screening.

\begin{tabular}{|c|c|c|}
\hline Name & Code & Sequence \\
\hline \multirow{2}{*}{ MseI adapter } & Ma1.1 & 5'-GAC GAT GAG TCC TGA G-3' \\
\hline & Ma1.2 & 5'-TAC TCA GGA CTC AT-3' \\
\hline \multirow[t]{2}{*}{ Pst $\mathrm{I}$ adapter } & Pa1.1 & 5'-GAC TGC GTA GGT GCA-3' \\
\hline & Pa1.2 & 5'-CCT ACG CAG TCT ACG AG-3' \\
\hline MseI primer + 1-C & MC00 & 5'-GAT GAG TCC TGA GTA AC-3' \\
\hline Pst $\mathrm{I}$ primer + 1-A & PA00 & 5'-GAC TGC GTA GGT GCA GA-3' \\
\hline $\mathrm{MseI}+3-\mathrm{CAG}$ & MCAG & 5'-GAT GAG TCC TGA GTA ACA G-3' \\
\hline$M s e I+3-\mathrm{CTC}$ & MCTC & 5'-GAT GAG TCC TGA GTA ACT C-3' \\
\hline$M s e \mathrm{I}+3-\mathrm{CAA}$ & MCAA & 5'-GAT GAG TCC TGA GTA ACA A-3' \\
\hline Pst $\mathrm{I}+3-\mathrm{AGA}$ & PAGA & 5'-GAC TGC GTA GGT GCA GAG A-3' \\
\hline Pst I + 3-AAT & PAAT & 5'-GAC TGC GTA GGT GCA GAA T-3' \\
\hline Pst $\mathrm{I}+3-\mathrm{ATA}$ & PATA & 5'-GAC TGC GTA GGT GCA GAT A-3' \\
\hline
\end{tabular}

A binary matrix was generated from the gel readings, and individual cultivars were assessed for the presence (1) or absence (0) of loci using this matrix. From this matrix, genetic dissimilarity was calculated using the Jaccard coefficient by using the NTSYSpc 2.1 software (Rohlf, 2000). The 20 garlic cultivars were grouped based on the genetic dissimilarity matrix using UPGMA. The robustness of the data was tested by bootstrap with 1000 repetitions. The cophenetic correlation for the AFLP markers was obtained by using the same methodology as that used for the morphological data.

\section{RESULTS AND DISCUSSION}

\section{Morphological characters}

Among the 28 morphological characters evaluated, two were not significant based on the F-test: presence and absence of external bulbils $(\mathrm{P}<0.32)$ and number of sticks per bulb ( $\mathrm{P}$ $<0.17)$. Thus, these characters were discarded from the subsequent analyses.

The quantitative characters with the highest contribution to divergence were plant height $(56.30 \%)$ and coat adhesion $(22.31 \%)$. The other analyzed characters were collectively responsible for only $21.39 \%$ of variation. The importance of plant height for estimating the divergence among the garlic cultivars studied here is consistent with the data presented by Mota et al. (2006), which considered this character to be essential to the morphological distinction of garlic cultivars. Other variables that also contributed to divergence estimates between culti- 
vars in this study were the lengths of leaves $(4.96 \%)$ and bulbils $(4.44 \%)$. The characters that made less contribution to divergence were leaf width $(0.08 \%)$, bulbil number $(0.12 \%)$, and bulb size $(0.13 \%)$, which were minor in comparison.

The average divergence detected using morphological characters was 2.30 [range, from 0.45 (Peruano and Chinês São Joaquim) to 4.70 (Cateto Roxo and Gigante Livina); Table 2]. The Peruano and Chinês São Joaquim cultivars differed in eight characters, including foliage density, leaf length, bulbil size, and coat adhesion. Other cultivars exhibiting slight divergence were Quitéria and Ito (0.73), and Bergamota and Ito (0.76), which differed in only five and six characters, respectively. Although the latter cultivars differed in fewer characters, they exhibited greater divergence than that estimated between the Peruano and Chinês São Joaquim cultivars. This may be due to the differences observed in plant height, which had the greatest effect on divergence calculations (Table 3). On the other hand, the Cateto Roxo and Gigante Livina cultivars differed in 20 characters and only had one common quantitative character of considerable importance (bulbil size).

The cophenetic correlation coefficient of the dendrogram generated using UPGMA revealed a poor fit between the graphical representation of distance and its original matrix $(\mathrm{r}=$ 0.71), indicating a slight distortion of the dendrogram when using morphological characters. The best fit is found when $r$ values are greater than 0.9 ; however, values above 0.7 were also considered to be significant for this analysis (Lapointe and Legendre, 1992).

By using a cutoff genetic distance of 2.10, the garlic cultivars in this study were separated into five groups on the dendrogram (Figure 1). Group A comprised eight cultivars from the noble group; groups B and C comprised one cultivar each, i.e., Caturra and Amarante, respectively; group D comprised the Chinês São Joaquim, Peruano, Cateto Roxo, and Gigante Roxão cultivars, and group E was made up of the rest of the cultivars from the semi-noble group. Although the Amarante and Caturra cultivars represented a transition zone between the noble (group A) and semi-noble cultivars (groups D and E), they were closer to the noble group on the dendrogram despite being classified commercially as semi-nobles. Mota et al. (2005) concluded that the use of four characters (plant height, leaf number, leaf width, and angle of leaf insertion) was not sufficient to divide the cultivars consistently into groups. Our data indicate that even the use of 28 morphological characters cannot definitively separate cultivars into the noble and seminoble groups, which are the commonly used classifications by farmers and traders.

\section{AFLP markers}

The average genetic divergence calculated using the 77 polymorphic AFLP markers that were amplified by three primer combinations was $43 \%$. Considering that garlic has an asexual reproductive system and therefore does not undergo genetic recombination, this level of polymorphism may be considered high. However, it is lower than that observed in many other species, e.g., the common bean (Phaseolus vulgaris L.), which exhibits 53.4\% divergence (Kumar et al., 2008). Higher polymorphism is understandable in species with sexual reproductive systems; it allows a higher level of recombination in these plants.

The genetic divergence ranged from 0\% (Chinês Real and Gigante Roxão) to 79\% (Ito and Chinês São Joaquim) (Table 2), which is in agreement with the findings reported by Lampasona et al. (2003) and Ipek and Simon (2001), who observed divergence values ranging $3-76$ and $5-70 \%$, respectively. 
R.G.F. Morales et al.

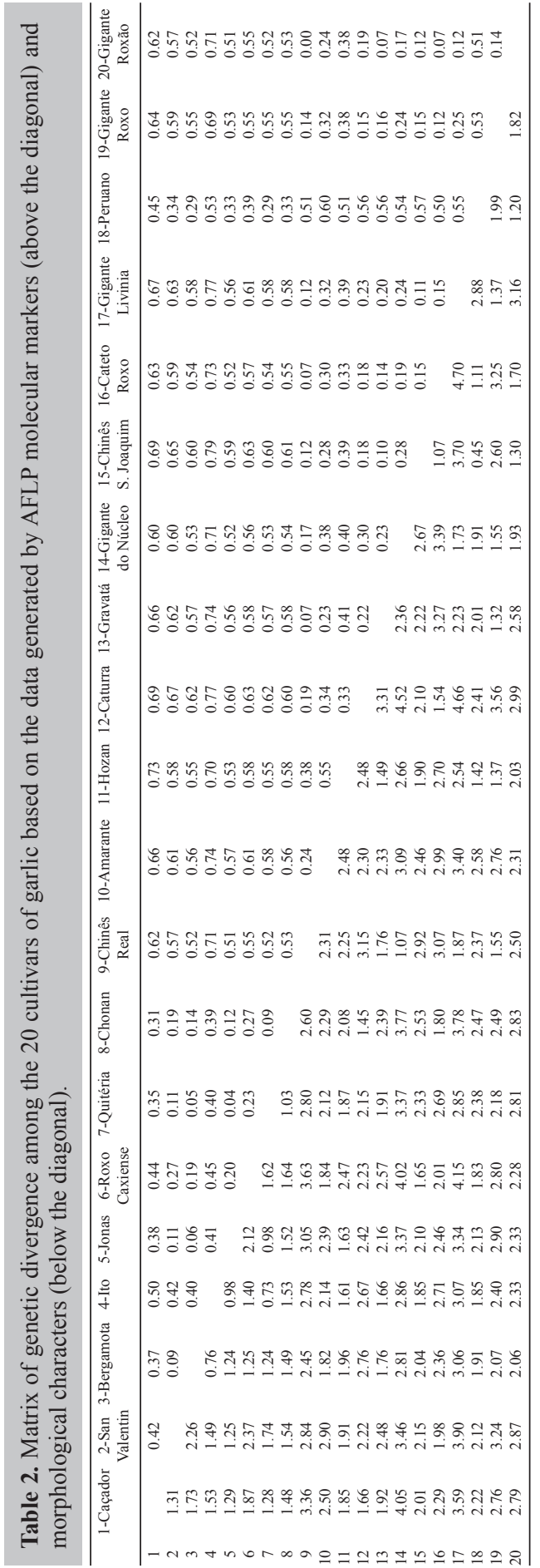


Table 3. Quantitative traits with the highest contribution to the calculation of genetic diversity in the cultivars of garlic.

\begin{tabular}{lcccc}
\hline Cultivars & Plant height $(\mathrm{cm})^{*}$ & Length of leaf $(\mathrm{cm})^{*}$ & Length of bulbil $(\mathrm{cm})^{*}$ & Adhesion of the coats $(\mathrm{seg})^{*}$ \\
\hline Caçador & $66.67^{\mathrm{d}}$ & $46.75^{\mathrm{d}}$ & $2.938^{\mathrm{b}}$ & $14.75^{\mathrm{e}}$ \\
San Valentin & $56.00^{\mathrm{i}}$ & $53.00^{\mathrm{a}}$ & $2.679^{\mathrm{b}}$ & $10.75^{\mathrm{e}}$ \\
Bergamota & $70.33^{\mathrm{b}}$ & $47.33^{\mathrm{d}}$ & $2.825^{\mathrm{b}}$ & $15.00^{\mathrm{e}}$ \\
Ito & $63.42^{\mathrm{f}}$ & $47.75^{\mathrm{d}}$ & $2.583^{\mathrm{b}}$ & $16.25^{\mathrm{e}}$ \\
Jonas & $66.25^{\mathrm{d}}$ & $49.25^{\mathrm{c}}$ & $2.392^{\mathrm{c}}$ & $16.50^{\mathrm{e}}$ \\
Roxo Caxiense & $71.42^{\mathrm{b}}$ & $50.92^{\mathrm{b}}$ & $2.592^{\mathrm{b}}$ & $22.50^{\mathrm{e}}$ \\
Quitéria & $65.25^{\mathrm{e}}$ & $47.17^{\mathrm{d}}$ & $2.617^{\mathrm{b}}$ & $19.25^{\mathrm{e}}$ \\
Chonan & $68.33^{\mathrm{c}}$ & $51.00^{\mathrm{b}}$ & $2.617^{\mathrm{b}}$ & $10.00^{\mathrm{e}}$ \\
Chinês Real & $58.67^{\mathrm{h}}$ & $38.25^{\mathrm{g}}$ & $2.754^{\mathrm{b}}$ & $33.50^{\mathrm{d}}$ \\
Amarante & $65.67^{\mathrm{e}}$ & $40.17^{\mathrm{f}}$ & $35.25^{\mathrm{d}}$ \\
Hozan & $60.25^{\mathrm{g}}$ & $39.58^{\mathrm{f}}$ & $2.200^{\mathrm{c}}$ & $19.25^{\mathrm{e}}$ \\
Caturra & $75.58^{\mathrm{a}}$ & $42.17^{\mathrm{e}}$ & $2.813^{\mathrm{b}}$ & $29.75^{\mathrm{d}}$ \\
Gravatá & $69.75^{\mathrm{b}}$ & $39.67^{\mathrm{f}}$ & $2.438^{\mathrm{c}}$ & $19.50^{\mathrm{e}}$ \\
Gigante do Núcleo & $66.50^{\mathrm{d}}$ & $37.25^{\mathrm{g}}$ & $2.463^{\mathrm{c}}$ & $28.75^{\mathrm{d}}$ \\
Chinês S. Joaquim & $67.25^{\mathrm{d}}$ & $39.00^{\mathrm{f}}$ & $3.325^{\mathrm{a}}$ & $1.750^{\mathrm{d}}$ \\
Cateto Roxo & $69.17^{\mathrm{c}}$ & $50.00^{\mathrm{b}}$ & $2.225^{\mathrm{c}}$ & $71.25^{\mathrm{a}}$ \\
Gigante Livinia & $63.25^{\mathrm{f}}$ & $38.58^{\mathrm{g}}$ & $2.879^{\mathrm{b}}$ & $28.25^{\mathrm{d}}$ \\
Peruano & $66.75^{\mathrm{d}}$ & $47.58^{\mathrm{d}}$ & $2.285^{\mathrm{c}}$ & $63.58^{\mathrm{c}}$ \\
Gigante Roxo & $67.83^{\mathrm{d}}$ & $41.42^{\mathrm{e}}$ & $2.591^{\mathrm{b}}$ & $25.43^{\mathrm{d}}$ \\
Gigante Roxão & $64.17^{\mathrm{f}}$ & $39.83^{\mathrm{f}}$ & $2.056^{\mathrm{d}}$ & $57.23^{\mathrm{c}}$
\end{tabular}

*Means followed by the same superscript letters in a column do not differ statistically from one another based on the Scott-Knott test $(\mathrm{P}<0.05)$.

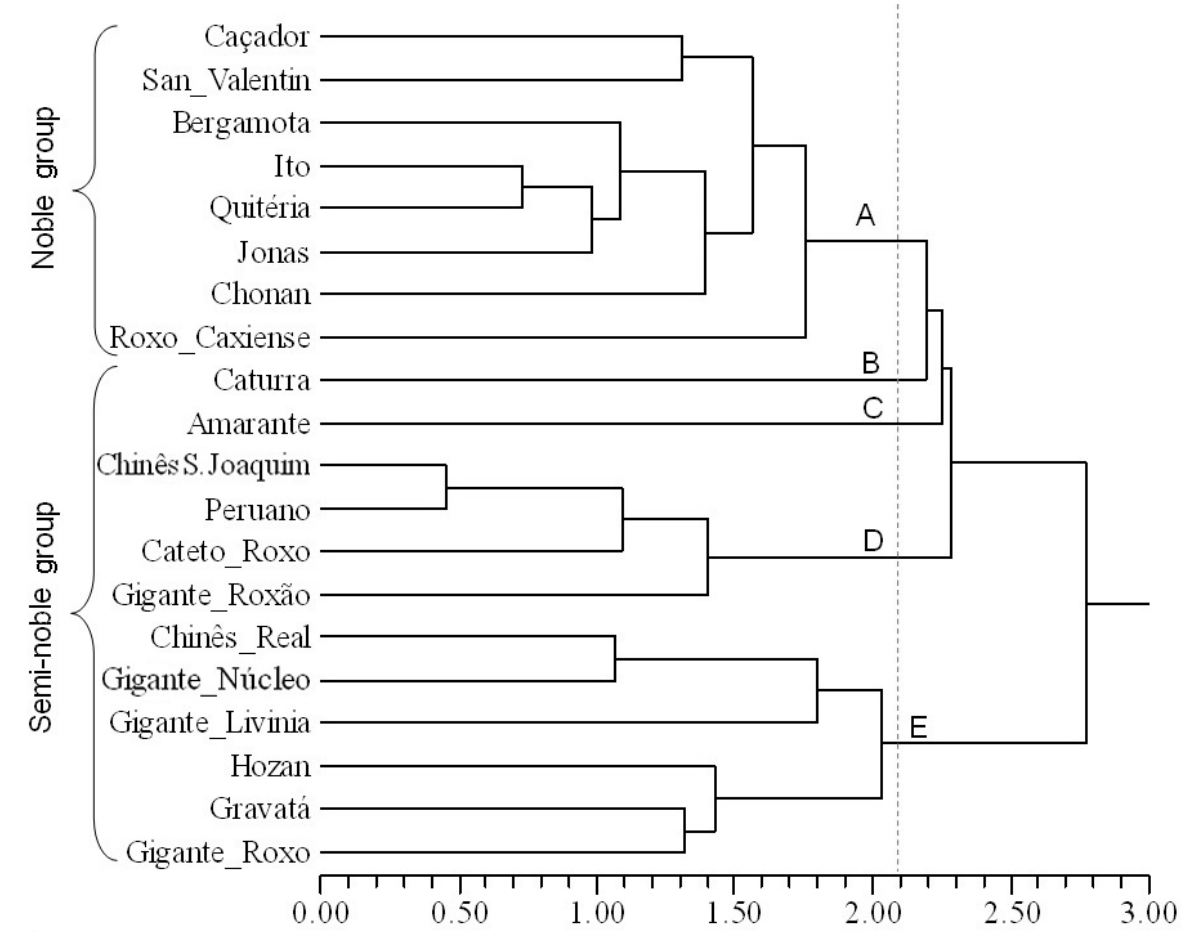

Figure 1. Dendrogram of genetic dissimilarity between the 20 garlic cultivars, obtained from morphological characters by using the UPGMA clustering method. The dotted line indicates the cutoff point for the formation of groups based on the average dissimilarity. The letters A, B, C, D, and E correspond to the groups formed based on the average dissimilarity. 
The cophenetic correlation coefficient between the Jaccard similarity matrix and the phenetic matrix was $r=0.96$, revealing an optimal fit between the distances and graphical representation of the original matrix (Rohlf, 2000) and enabling accurate inferences by visual evaluation of the dendrogram. The robustness of the dendrogram was confirmed by bootstrap values $(>50 \%)$ at the main bifurcation of the dendrogram (Figure 2 ).

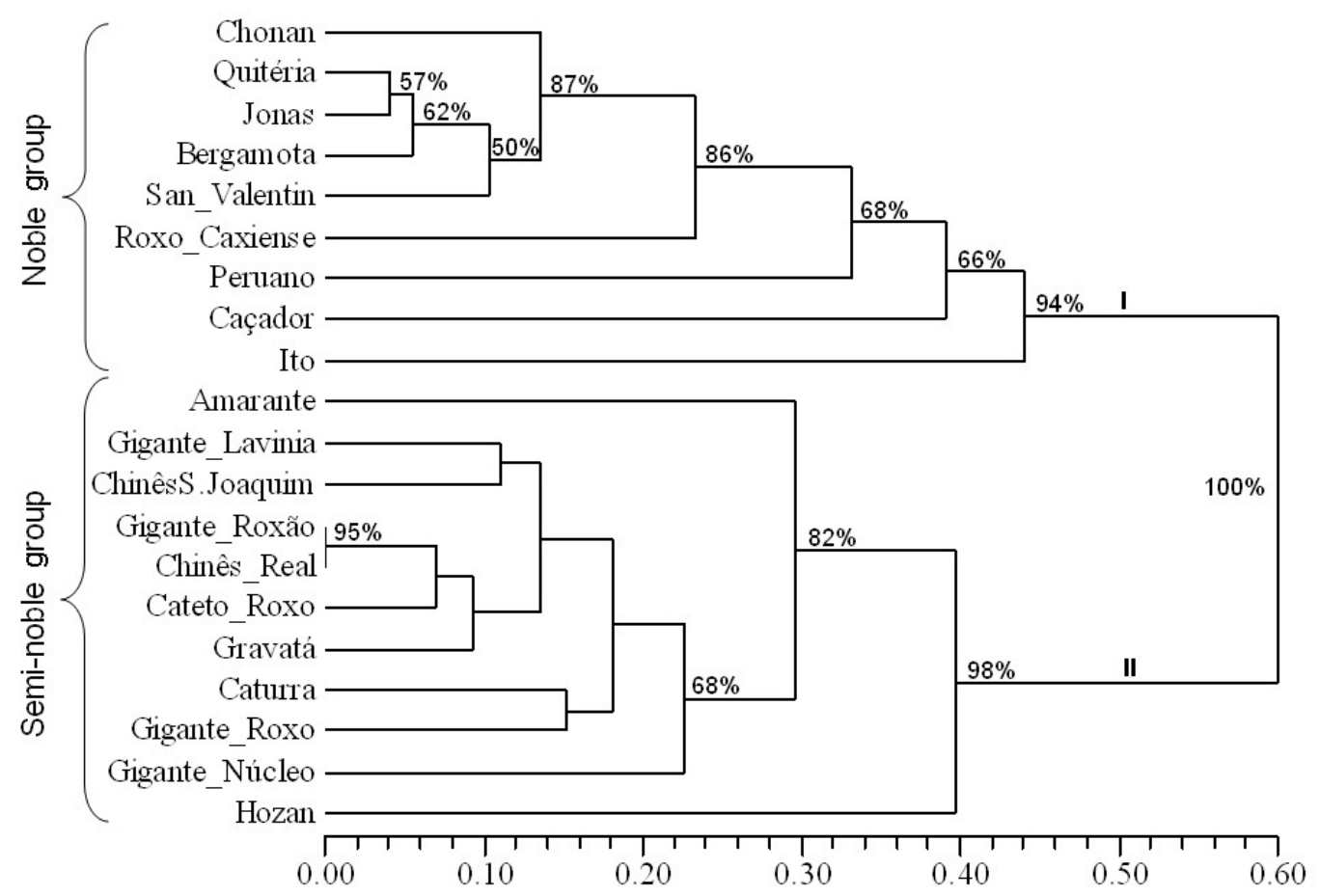

Figure 2. Dendrogram of genetic dissimilarity among the 20 varieties of garlic, constructed with the data generated by AFLP markers by using the Jaccard coefficient and UPGMA clustering method. I and II signify the groups that are formed in accordance with the commercial designations, i.e., noble and semi-noble. Bootstrap support values are shown at the junctions.

On the dendrogram, AFLP markers classified the cultivars into two groups (noble and semi-noble), which is consistent with the classification of farmers and traders. Similar results were obtained using random amplified polymorphic DNA (RAPD) markers (Buso et al., 2008). Another common factor between these studies was the high genetic similarity between the Quitéria and Jonas cultivars (96\%). In addition, we observed 10 other similarity values above $90 \%$, including those for the Chinês Real and Gigante Roxão cultivars, which exhibited $100 \%$ similarity. Other studies based on both isoenzyme and morphologic characters of garlic cultivars also reported similar results (Augustin and Garcia, 1993). These findings support the hypothesis of the presence of duplicate cultivars bearing different names.

The only cultivar that was grouped by AFLP markers outside its group of origin was the Peruano cultivar, which was classified commercially as semi-noble, but grouped here with the noble cultivars (Figure 2). 


\section{Comparative analysis of morphological and molecular markers}

Based on the AFLP data, the Chinês Real and Gigante Roxão cultivars could be considered clones. The Jonas and Quitéria cultivars in the noble group, which exhibited low levels of divergence based on AFLP data, also exhibited little divergence when morphological character data were considered. In general, the average correlation between genetic divergence estimates obtained by the two methods was low (22\%). When the analysis was partitioned by group (noble and semi-noble), the correlations were found to differ, and in many cases, a negative correlation was observed between estimates calculated using the two methods. The correlation of genetic divergence in the noble group was $61 \%$, whereas that in the semi-noble group was $-5 \%$. The higher correlation in genetic dissimilarity among the cultivars of the noble group may be related to the phenotypic stability of the cultivars of this group, making it possible to express their characteristics in a wider range of environments.

The agronomic superiority of the cultivars from the noble group was also apparent when comparing the divergence estimates within this group with those of the semi-noble group. Based on the AFLP markers, noble cultivars were 13\% less divergent than the seminoble cultivars. When data based on morphological characters were used, this value increased to $61 \%$. The smaller divergence estimates based on morphological characters within the noble group, along with the correlation between the methods described above, help explain the higher quality of the cultivars from this group, possibly because of increased phenotypic stability as compared to that of the cultivars in the semi-noble group, which is so far only demonstrated by examination of phytotechnical data.

The use of clones with different regional names is common in many parts of the world. Analysis of a collection of garlic in the United States of America by Volk et al. (2004) showed that $41 \%$ of the cultivars were duplicates. Vieira and Nodari (2007) evaluated the genetic similarity of 20 garlic cultivars with RAPD markers and observed the following possible clones with 100\% genetic similarity: Fuego-INTA, Caxiense, and Colorado; Softsteim, Hardsteim, and Russo; Caçador 40 and Caçador 30, and Jonas and Quitéria, which was similar to that observed in our study. Importantly, the San Valentin cultivar has several regional names, being referred to as San Valentin in Rio Grande do Sul, Esmeralda in Santa Catarina, and Caxiense in Paraná (Vieira and Nodari, 2007). The same has been reported for the Ito and Caçador cultivars, and it is suspected that the Ito cultivar is a selected form of the Caçador cultivar. However, in this study, we did not observe morphological or molecular similarities between these two cultivars.

The Brazilian garlic cultivar classification system is based on morphological characters and production cycle (Menezes Sobrinho et al., 1999). Morphological data from this study demonstrated that this technique is useful for distinguishing cultivars between groups, but is limited in its ability to distinguish cultivars within groups. In contrast, the use of AFLP markers proved to be an efficient method for distinguishing cultivars both within and between groups, as noted previously (Ipek and Simon, 2001; Ipek et al., 2003; Lampasona et al., 2003; Volk et al., 2004). However, conclusions based solely on molecular data must be treated with caution, because cultivars that are determined to be identical using these data often have contrasting agronomic performance, as observed in this study for the Gigante Real and Chinês Real cultivars. These findings indicate that inferences that are more reliable can be made when using the two techniques in conjunction than when using either technique alone. 


\title{
CONCLUSION
}

The use of morphological characters is an effective way to distinguish garlic cultivars between groups; however, it is insufficient for characterization within groups. AFLP markers efficiently distinguish cultivars between and within groups, and are able to reveal highly similar cultivars. In this study, the correlation between morphological and molecular data, together with the divergence within groups, made it possible to infer that the noble cultivar group has greater phenotypic stability than the semi-noble cultivar group. The two techniques revealed that the Jonas and Quitéria cultivars have limited divergence; therefore, they may be clones or possess a high degree of kinship.

\section{ACKNOWLEDGMENTS}

\author{
Research supported by Fundação Araucária de Apoio ao Desenvolvimento Científico \\ e Tecnológico do Paraná.
}

\section{REFERENCES}

Augustin E and Garcia A (1993). Classificação isoenzimática, morfológica e agronômica de genótipos de alho. Hortic. Bras. 11: 10-13.

Baghalian K, Naghavi MR, Ziai SA and Badi HN (2006). Post-planting evaluation of morphological characters and allicin content in Iranian garlic (Allium sativum L.) ecotypes. Sci. Hortic. 107: 405-410.

Bark OH and Havey MJ (1995). Similarities and relationships among populations of the bulb onion as estimated by nuclear RFLPs. Theor. Appl. Genet. 90: 407-414.

Buso GS, Paiva MR, Torres AC, Resende FV, et al. (2008). Genetic diversity studies of Brazilian garlic cultivars and quality control of garlic-clover production. Genet. Mol. Res. 7: 534-541.

Cruz CD (2006). Programa GENES: Análise Multivariada e Simulação. Imprensa Universitária, Viçosa.

Etoh T, Watanabe H and Iwai S (2001). RAPD variation of garlic clones in the center of origin and the westernmost area of distribution. Mem. Fac. Agric. Kogoshima Univ. 37: 21-27.

Filgueira FAR (2008). Novo Manual de Olericultura. UFV, Viçosa.

Ipek M and Simon PW (2001). Genetic diversity in garlic (Allium sativum L.) as assessed by AFLPs and isozymes. HortScience 36: 454

Ipek M, Ipek A and Simon PW (2003). Comparison of AFLPs, RAPD markers, and isozymes for diversity assessment of garlic and detection of putative duplicates in germplasm collections. J. Amer. Soc. Hort. Sci. 128: 246-252.

Kumar V, Sharma S, Kero S, Sharma S, et al. (2008). Assessment of genetic diversity in common bean (Phaseolus vulgaris L.) germplasm using amplified fragment length polymorphism (AFLP). Sci. Hortic. 116: 138-143.

Lallemand J, Messian CM, Briand F and Etoh T (1997). Delimitation of varietal groups in garlic (Allium sativum L.) by morphological, physiological and biochemical characters. Acta Hort. 433: 123-132.

Lampasona SG, Martínez L and Burba JL (2003). Genetic diversity among selected Argentinean garlic clones (Allium sativum L.) using AFLP (amplified fragment length polymorphism). Euphytica 132: 115-119.

Lapointe FJ and Legendre P (1992). Statistical significance of the matrix correlation coefficient for comparing independent phylogenetic trees. Syst. Biol. 41: 378-384.

Li Z, Liu XQ, Gituru RW, Juntawong N, et al. (2010). Genetic diversity and classification of Nelumbo germplasm of different origins by RAPD and ISSR analysis. Sci. Hortic. 125: 724-732.

Maab HI and Klaas M (1995). Infraespecific differentiation of garlic (Allium sativum L.) by isozyme and RAPD markers. Theor. Appl. Genet. 91: 89-97.

Menezes Sobrinho JA, Charchar JM and Aragão FAS (1999). Caracterização morfológica de germoplasma de alho por análises multivariada componentes principais e variáveis canônicas. Hortic. Bras. 17: 96-101.

Morales RGF, Resende JTV, Faria MV, Andrade MC, et al. (2011). Genetic similarity among strawberry cultivars assessed by RAPD and ISSR markers. Sci. Agric. 68: 665-670.

Mota JH, Souza RJ, Yuri JE, Rezende GM, et al. (2005). Similaridade morfológica de cultivares de alho (Allium sativum L.). Rev. Cien. Eletr. Agr. IV. 
Mota JH, Yuri JE, Resende GM and Souza RJ (2006). Similaridade genética de cultivares de alho pela comparação de caracteres morfológicos, físico-químicos, produtivos e moleculares. Hortic. Bras. 24: 156-160.

Murray MG and Thompson WF (1980). Rapid isolation of high molecular weight plant DNA. Nucleic Acids Res. 8: 43214325.

Ovesná J, Kucera L, Králová J, Leišová L, et al. (2007). Genetic diversity among garlic clones as revealed by AFLP, phenotypic descriptors and S-amino acids level. Vegetable Crop Res. Bull. 66: 105-116.

Pooler MR and Simon PW (1993). Characterization and classification of isozyme and morphological variation in a diverse collection of garlic clones. Euphytica 68: 121-130.

Rohlf FJ (2000). NTSYS-PC Numerical Taxonomy and Multivariate Analysis System. Version 2.1. Applied Biostatistics, New York.

Singh D (1981). The relative importance of characters affecting genetic divergence. Indian J. Genet. Plant Breed. 41: 237-245.

SNPC (2012). Sistema Nacional de Proteção de Cultivares: Alho. Available at [http://www.agricultura.gov.br/arq editor/file/vegetal/RegistroAutorizacoes/Formularios $\% 20$ Prote $\% \mathrm{C} 3 \% \mathrm{~A} 7 \% \mathrm{C} 3 \% \mathrm{~A} 30 \% 20 \mathrm{Cultivares} / \mathrm{ALHO} \% 20$ FORMULARIO\%2008DEZ2005P\%20ATUALIZADO\%20EM\%2031\%2007\%202008.doc]. Accessed February 1, 2012.

Sokal RR and Rohlf FJ (1962). The comparison of dendrograms by objective methods. Taxonomy 11: 30-40.

Thomaz EL and Vestena LR (2003). Aspectos Climáticos de Guarapuava, PR. Unicentro, Guarapuava.

Vieira RL and Nodari RO (2007). Diversidade genética de cultivares de alho avaliada por marcadores RAPD. Ciênc. Rural 37: 51-57.

Volk GM, Henk AD and Richards CM (2004). Genetic diversity among U.S. garlic clones as detected using AFLP methods. Amer. Soc. Hort. Sci. 129: 559-569.

Vos P, Hogers R, Bleeker M, Reijans M, et al. (1995). AFLP: a new technique for DNA fingerprinting. Nucleic Acids Res. 23: 4407-4414. 